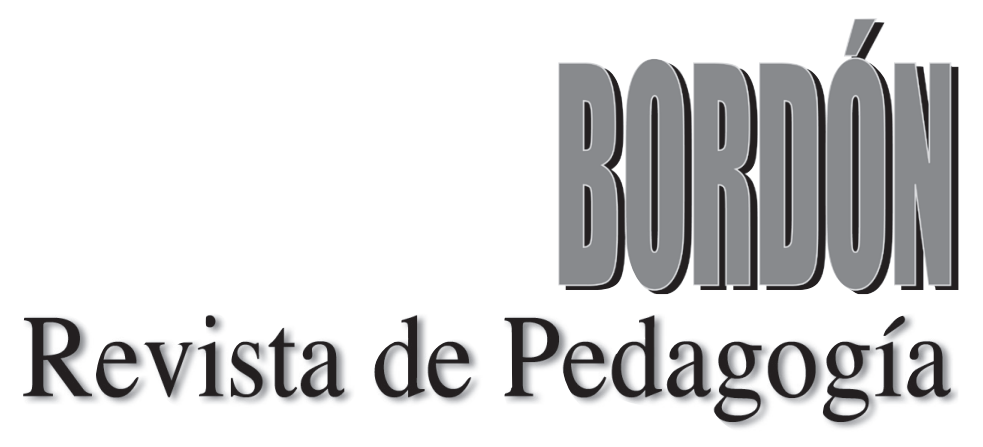

NÚMERO MONOGRÁFICO / SPECIAL ISSUE

Ética y universidad /
Ethics and university
Francisco Esteban y Pádraig Hogan
(editores invitados / guest editors)

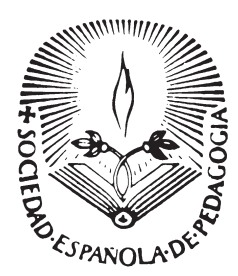

\author{
Volumen 69 \\ Número, 4 \\ 2017
}




\title{
SHAPING A NEW ETHICAL LAIDSCAPE IN TEACHER EDUCATION: An IRISH EXPERIENCE In An IITERnATIONAL CONTEXT
}

\section{Dando forma a un nuevo paisaje ético en la formación de maestros: una experiencia irlandesa en un contexto internacional}

\author{
ROSE DOLAN \& PÁDRAIG HOGAN \\ National University of Ireland Maynooth
}

D01: 10.13042/Bordon.2017.690407

Received date: 01/02/2017 - Accepted date: 31/05/2017

Corresponding Author: Dr Rose Dolan. E-mail: rose.dolan@ nuim.ie

INTRODUCTION. This article reviews a gradual but decisive transformation in teacher education in Ireland. It traces, firstly, the outlines of traditional models of teacher education - based historically on UK patterns. These rarely addressed directly the ethical dimensions of professional learning. Such learning largely consisted of acquaintance with a body of theory on the one hand, and on the other, initiation into inherited attitudes and practices for survival in the workplace. The article examines successive efforts to change these models. METHOD. Taking as an illustrative study the efforts of one university to transform this pattern, we explore how a new rationale emerged during the 1980s and progressively came to fruition thereafter. Critical attention is paid to concerns like the teacher's ethical agency and reflective capacity. The research structure has five parts. The first sketches the historical context, revealing how key ethical questions often remained peripheral in teacher education. The second traces the different directions taken by teacher education in the UK and Ireland in the 1980s and provides a summary of the new rationale we developed at Maynooth. The third reviews the notion of teachers' ethical agency, and its importance for that rationale. The fourth illustrates how the new rationale changed the experience of becoming a teacher, specifically through the Higher Diploma in Education. The final section reviews the consequences of the new approach and its broader import for national policy at a time when Ireland's Teaching Council progressively embraced a critically reflective approach to teacher education as a whole. RESULTS. The results of the new approach are reviewed incrementally through the paper, to reveal how the ethical dimensions of professional learning became more central and more fruitful. DISCUSSION. The discussion, throughout the paper, focuses on the actions needed to make the ethical dimensions of professional learning more relevant and meaningful.

Keywords: Ethical agency, Reflective capacity, Research-informed practice. 


\section{Introduction}

Since the early 1980s student teachers on the postgraduate Initial Teacher Education (ITE) programme in our university, namely the Higher Diploma in Education (HDE), have engaged in self-appraisal and peer-appraisal as part of the programme. Processes such as video and audio analysis of classroom practice and assignments became central, focusing on the critical exploration of the students' autobiographies as learners. Such processes helped them, as found by a 2002 evaluation study, to "develop critical self-awareness, gain insights into their own classroom practice, analyse the implications of their actions in the classroom and overall, confront the quality of their teaching" (Drudy and Uí Chatháin, 2002: 35).

At the beginning of the $21^{\text {st }}$ century, a number of former secondary teachers joined the university's Education Department and a further shift in emphasis in the HDE programme took place. Incremental changes were made by the staff; changes that had strong resonance with an action research approach to professional development. Engagement with reflective practice intensified, inspired by Brookfield's work on critical reflection (Brookfield, 1995). This article reviews how forms of professional preparation which were traditionally rites of introduction to a subservient order became transformed. It puts the spotlight on how this was accomplished in our own university, while pursuing a vision of education as a practice in its own right; a practice which is at its heart critical, reflective and co-operative.

\section{The Historical Background}

The traditional pattern of ITE in Ireland can be described fairly quickly. That pattern became established well before the country's independence from the United Kingdom in 1922, so it was similar in key respects to the UK pattern. For trainee primary teachers courses were provided in training colleges rather than in universities and they led to the award of a teacher's diploma after two years of study. Trainee secondary teachers followed a one-year postgraduate course in university, leading to the HDE. To enrol on a course for this diploma applicants needed a primary degree, most often a B.A. or a B.Sc., awarded after three years' study as a university undergraduate. For teachers of technical-practical subjects at secondary level, there were two-year courses, or sometimes three-year courses, available in a few small training colleges.

After independence there was little structural change. The basic pattern of ITE remained fundamentally the same for more than a further half-century. The first major changes came in the mid-1970s, when teaching became an allgraduate profession. The two-year courses for primary teachers were restructured as threeyear courses leading to a B.Ed. degree. The courses still took place in training colleges (now renamed as Colleges of Education) rather than in universities, although these colleges became 'recognised colleges' of universities. Similar developments were taking place in the UK at that time. But courses for secondary teachers remained largely untouched by these reforms of the seventies. A notable exception was that a handful of small B.Ed.- type courses of four years' duration were inaugurated on a few campuses at the time, for teachers of subjects like Physical Education, Home Economics, Religious Education and Art. But these didn't become a model for others to follow and the HDE remained the main route to qualification for the great majority of Ireland's secondary teachers.

The next major change to ITE, which marked the beginning of a third distinct era, occurred at the beginning of the second decade of the twenty-first century (2011). The Irish government's Department of Education and the Teaching Council (the new statutory body for regulating the teaching profession) extended 
B.Ed.-type courses to four years, and HDE courses from one year to two. This policy action was based on research studies, and on commissioned reports and policy documents on ITE from 1991 onwards. Swiftly on the heels of this policy change came a further major development: a government decision in 2012 to restructure Ireland's twenty-six teacher education institutions or departments into six 'Institutes', each of the six becoming integral to one or other of the country's universities. The first change was to be accomplished by 2015 and the second by 2016 .

From these opening remarks it can be gathered that quite different conceptions of ITE prevailed in each of the three main periods just outlined. Underlying these differences moreover lay quite different views on the ethical agency of teachers. The first period, namely the halfcentury from the mid-twenties to the midseventies, could fairly be called a conservative period; but it is important that the term is understood as a description, not a judgement. The second period, from the mid-seventies to the end of the first decade of the twenty-first century, could rightly be called a mixed era, where significant changes in some areas of ITE were matched by little change in others. The third period, although it is still in its early days, can already be seen as one of transformation. Such historical periods have parallels in many countries, though the timing, and the dominant character of each one, may vary from one country to another.

In the exploration that follows here we shall review what the changes have meant for the ethical agency of teachers; that is, for their capacity and their scope to influence for the better the educational lives of their students. Our own university, the National University of Ireland Maynooth, began to develop a fresh rationale for secondary ITE in the early 1980s, involving some video-recording of teaching placements in schools and follow-up analysis by the student teachers in the university.
Later, as we shall see, it played an active role in promoting some of the changes associated with the third period. But it was also taking some pioneering initiatives in ITE during the second period, though in less conspicuous ways. Maynooth therefore serves as a useful case study for our review. The issues examined in that review will also be considered however in the context of wider changes, nationally and internationally.

\section{Parting of Ways and Building New Paths}

In Ireland's case the character of the educational system in the first half century after independence (1922) was strongly paternalistic. Unlike other countries however, where church and state fought each other for the control of schooling, the newly independent Irish government deferred continually to the Catholic church in matters of social and educational policy. ${ }^{1}$ ITE institutions, including the education departments of most universities, remained strongly influenced by Catholic orthodoxy until the late sixties or early seventies. The introduction of a learnercentred primary curriculum in 1971, and of the three-year B.Ed. courses for primary teachers during the mid-seventies, marked the start of the second of the three eras identified above. Some important shifts now began to take place in the professional cultures of ITE. Research perspectives became central in the students' studies. They were largely introduced through traditional lecture courses in four main disciplines of educational studies, commonly referred to as 'theory' courses: sociology of education, educational psychology, history of education, philosophy of education. We have remarked earlier that the B.Ed. courses were chiefly for primary teachers and that the longstanding HDE course continued as the main route for intending post-primary teachers. The four theory disciplines also became firmly established in the HDE. The courses for both 
primary teachers and post-primary teachers thus became more theoretical.

Insufficient attention was paid during these changes however to the question of how the new theoretical studies would inform the professional ethics of student teachers. Many criticisms were made over the following decades of a rift between the theory that student teachers studied in college and the practical learning that took place during their teaching placements in schools. Such criticisms were voiced in many countries of course, and can still be heard. In the United Kingdom, particularly England, the criticisms of 'theory' gathered a strong political force during Margaret Thatcher's three terms as prime minister (19791990). Neoliberal campaigners there urged strong government action, and successfully so; for instance the Hillgate Group's manifesto of 1989, Learning to Teach, and Sheila Lawler's provocatively titled critique of the following year, Teachers Mistaught: Training in Theories or Education in Subjects? (1990). In the policy climate created by the 1988 Education Reform Act, ITE in England, Wales and Norther Ireland was restructured during the 1990s, with the traditional foundation courses being replaced by 'competences' approaches. By 1998, in Northern Ireland there were no fewer than 92 competences to which the goals of ITE courses had to be aligned (DENI, 1998). The changes in the UK were strongly resisted by most in the field of educational research. Teacher educators criticised the 'deskilling' of teachers and the systematic replacement of teachers' ethical agency by enforced compliance with government imposed goals and targets. There are some illuminating studies of this period in the UK to be found in Gilroy, 1998, 2003; Maclure 2008.

These policy developments in the UK marked a decisive parting of ways between the tenor of ITE there and in Ireland. The five principles underlying Ireland's 1998 Education Act arose from a national educational debate during the nineties and they give some indication of the parting of ways with the UK. These five principles are: partnership, pluralism, quality, equality, accountability (Government of Ireland 1998). The 1998 Act marked a further decline in church influence in education, though it is true to say that the churches (mainly the Roman Catholic Church) still retained some of their historic powers, particularly in the control of primary education. In any case, the climate in Ireland during the nineties, and more so in the new century, was hospitable to the introduction of initiatives with a fresh ethical tenor in ITE by universities themselves.

In the case of our own university such initiatives involved a move to get the students more directly participating as constructive critics of their own professional learning. The new rationale which had begun in the early 1980s was now, at the beginning of the new century, actively expanded. It became more closely informed by research perspectives, and particularly by 'reflective practitioner' perspectives. The decisive developments in that expansion are reviewed in the second next section of the article, after the notion of agency has been explored and clarified in the next section. In the remainder of this current section however it is worth highlighting the main characteristics of the new rationale itself. This rationale eschews a 'competences' approach to ITE, together with its emphasis on behaviourally defined skills that are assessed independently of each other (Dolan \& Gleeson, 2007). The rationale involves an 'ontological turn' (Aldridge, 2015), focusing in particular on cultivating the student teachers' selfunderstanding and capacity for pedagogical action. Accordingly, it seeks to enhance the student teachers' own experiences of learning, their pedagogical insights, their moral energies, their communicative capabilities and, not least, their capacity to work co-operatively in critiquing their own practice. Such a rationale brings together insights reclaimed from an original Socratic tradition with insights from 
recent work in reflective practice researches. These more recent insights include, for instance, Dewey (1938/1995), Gadamer (1995), Brookfield (1995), Munby \& Russell (1994), Oosterheert et al. (2002). What the distinctive ethical orientations of this rationale mean for the learning practices of student teachers, and for our own work as teacher educators, didn't become disclosed all-at once, or indeed in a few landmark revelations. Rather, as we have been intimating above, it grew incrementally from sources like the following: from our reflections on our work with students, teachers and school leaders; from our readings of research literature; from our research projects; from exchanges with educational policymakers and the national support agencies in education. Notwithstanding its many sources the main features of the rationale can be summarised in the following points:

a) In contrast to conceptions of teaching and learning which give pride of place to one or more forms of transmission, formal education is conceived in a more promising and more defensible way when it is understood as an open-ended quest, whatever the field in question; a quest that is collectively and individually engaged in by students, often led by an educator, though not necessarily so.

b) To engage fruitfully in this quest, students need to become sufficiently fluent in the field in question to join a keenly-focused exploration. An important point here is that such exploration can take place at many levels, beginning with the most rudimentary and proceeding to the most advanced venturings.

c) The effort required in becoming fluent is stimulated and supported by uncovering an appetite to understand better and to know more. This appetite can itself be cultivated by a teacher's actions in promoting high-quality learning experiences. And here there are two important steps: firstly the teacher's perceptive leadership of a joint exploration of new conceptual and imaginative neighbourhoods; secondly, the continual renewal of a desire to become more at home in such neighbourhoods - science, art, history, religion, etc. - thus overcoming in some degree one's previous limitations, biases and even aversions.

d) Even where the teacher is already familiar with the paths being explored, he/she is ever-ready to travel them afresh with new groups of students, and to discover new things along the way. The teacher himself/herself remains a committed student.

e) The spirit of exploratory learning can be greatly nourished by a greater diversity of learners in a learning environment. But it can also be threatened, or even undermined by any forms of chauvinism, belittlement, exclusion or favouritism.

f) For teachers to cultivate attitudes and practices such as these in learning environments, their own education as teachers needs to embody them in their own practices of professional learning, thus becoming ethically disposed in certain ways rather than others; ways that are definitive of education itself as a distinctive practice.

g) This point about dispositions is doubly true of teacher educators. But it carries an additional necessity - namely a commitment to ongoing research that can further illuminate the practice and uncover new possibilities for its enhancement.

This rationale, we should like to add, is provisional in character. That is to say it remains continually open to critique with a view to its own improvement. To understand more clearly however the transformative nature of the approaches springing from the rationale, it is now necessary to look more particularly at the meaning and significance of the ethical agency of teachers. 


\section{The Teacher's Ethical Agency}

Let us begin here by observing that the term 'the teacher's ethical agency.' is a more specific term than the widely-used one 'the teacher's professional scope'. The ethical agency of teachers refers to their capacity to discern what is needed to make learning environments healthy and fruitful; the capacity moreover to use their influence in such environments in imaginative, energetic and educationally defensible ways. Criticisms of restrictions in teachers' professional scope, and of the 'deskilling' of teachers, have frequently been voiced internationally in recent decades by opponents of test-driven educational reforms. But amid all concerns about professional scope and deskilling, rarely does one hear reference to anything as concrete and as fundamental as the curtailment of teachers' ethical agency. Wherever the opportunity to open up new imaginative landscapes - in maths, geography, Spanish etc. - is systematically restricted, the capacity to do so begins to diminish. And in that degree the solidarity that defines a healthy learning environment evaporates. This should concern the critics much more than it seems to. Perhaps it does, but the prevailing critical language is inadequate if it doesn't reach for something more insightful than commonplace terms - like 'deskilling and 'professional scope' - that don't reach to the heart of the matter. A brief consideration of what attracts people to teaching as an occupation, and what keeps them fulfilled and renewed there, should help to illustrate the importance of this point.

Research studies conducted with teachers that have been published in different parts of the Anglophone world over the last 25 years are remarkably consistent on the reasons why people enter teaching. This research shows that such reasons ('motivations' if you wish) are manifold. But consistently to the fore in what teachers themselves report is what is regularly called the 'altruistic motive': a desire to make a difference for the better in the lives of learners.
By contrast, aspirations for financial reward feature rarely if at all among the reasons offered (Alexander, Chant \& Cox, 1994; Johnson, Berg $\&$ Donaldson 2005; Marshall, 2009; Lawlor, 2014). It should be mentioned here however that some countries have had difficulties in recruiting promising candidates for teaching and have had to consider incentives, including financial ones, to attract sufficient applicants (Eide et al. 2004; OECD, 2005; Howson, 2012).

Of course the desire to make a difference for the better can be fulfilled in many other walks of life; but where teaching is concerned it means becoming communicatively discerning and capable in a number of key domains - for instance in one's relationships to the subjects being taught, to the students, to colleagues, to parents and so on. This becoming-capable is, at its core, an ethical matter. More precisely, it is the gradual, perceptive discovery of an ethical orientation to which one's thinking and actions as a teacher thenceforth become attuned. Something of this kind occurs in most walks of life that seek to serve some public good: becoming a nurse, a doctor, a community worker, an engineer, and so on. In the case of teaching as an occupation however, the core of the matter always and everywhere involves learning; even more than it involves teaching itself. This includes a specialised and prolonged learning-about, as is the case in other occupations and professions. But it also involves a learning-with and a reflexive learning (learning to know oneself and the less evident effects of one's interpersonal actions), to a degree that isn't called for in other occupations. There are strong resonances here of what authors like Stenhouse (1979/2012) and Elliott (2012) call the 'teacher as researcher', but with a specific and sustained emphasis on the teacher's capacity for ethical action through the teaching of his/her subjects.

This reflexive learning is arguably the most crucial in becoming a teacher, as the quality of all the other learning one does, either as a 
student teacher or a more experience teacher, depends on it. This is what is meant by an ontological shift, and it needs a few words of explanation. In short, a teacher who has an educated sense of his or her own ignorance is embarked from the start on a different road from the teacher who acquiesces in a picture of herself as expert, or indeed as a transmitter of knowledge, skills and understanding. One of the most striking examples of such a contrast in Western literature is that between Socrates on the one hand and the Greek sophists on the other. Leaving aside all talk of so-called 'Socratic method', there is an insight to be reclaimed here which such talk usually beclouds. As one who was reflectively involved in educational work for most of his life Socrates came to an important conclusion which he still continually put to the test in his educational encounters: Even the most successful of human efforts to gain knowledge and understanding remain partial, and in both senses of that word: (a) incomplete; (b) coloured by biases, many of which lie beyond our conscious awareness ${ }^{2}$. Human pretentions to absolute knowledge, or to knowledge that claimed to be free of all error, are therefore mistaken. On a Socratic view, one would need to be a divinity, as distinct from a mere human, to escape the bounds of partiality. Or as Socrates himself put it during his trial: 'Real wisdom is the property of God and this oracle [at Delphi] is his way of telling us that human wisdom has little or no value' (Apology 23a, Plato 1999). On such an account it would be foolhardy for mortals to play at being God, and particularly so for teachers and schools to entertain such pretensions.

All of this contrasts strongly with any picture of the teacher as the possessor of truth, or even of knowledge, which is then transmitted incrementally to students or pupils. But this has been the more dominant understanding of formal learning in the history of Western education, from Socrates' own time onwards. Custodial conceptions of teaching and learning have tended to dominate in the history of
Western education - for many centuries in ecclesiastical form, but also in political forms in more recent centuries. In fact the prevalent tenor of educational reform internationally in recent decades - with some notable exceptions - has tended to cast schools as compliant subordinates to the demands of the current party in power. Very many governments in Western democracies - including centre-left and centre-right — made policy reforms from a neoliberal stance, thus requiring new forms of servitude and compliance on the part of teachers (Sahlberg, 2011). This all but eclipses the ever-vulnerable notion of teaching as a practice in its own right. In such circumstances, which are not nearly as pronounced in Ireland as in other countries, it becomes particularly important to reclaim and elucidate the notion of the ethical agency of teachers.

A keenly thought-out understanding of teachers' ethical agency not only helped to inform at its heart our developing rationale for ITE. It also made us more critically conscious the dangers in what Sahlberg has called an international virus: the Global Education Reform Movement, or GERM for short (Sahlberg, 2011, p.99ff). Both the richer understanding of teachers' ethical agency and our consciousness of the inclement atmosphere of international reform, sharpened our attentions in building improvements into our own ITE courses. We now take up that story again from where we left off from it in the previous section, namely at the turn to the new century.

\section{The New Rationale In Action: Reforming the Higher Diploma in Education}

As mentioned earlier, since the early 1980s student teachers in our university have engaged in self-appraisal and peer-appraisal as part of the programme. Student teachers were videotaped in their placement schools and these videos were then analysed in small peer groups, facilitated 
by staff from the university's Education Department. During the programme, they also completed an assignment using the Flanders Interaction Analysis Coding System (FIACS) (Flanders, 1970). This required them to record a typical lesson and to then code and analyse it in order to "develop critical self-awareness, gain insights into their own classroom practice, analyse the implications of their actions in the classroom and overall, confront the quality of their teaching" (Drudy and Uí Chatháin, 2002: 35). Finally, a Semester One assignment gave them the option to critically explore their autobiographies as learners as sources of insight into their practices as student teachers (Brookfield, 1995).

At the beginning of the $21^{\text {st }}$ century, a number of former second-level teachers joined the Education Department and a further shift in emphasis in the HDE took place. This was firstly evident in the foundation disciplines (educational psychology, philosophy of education, sociology of education, history of education) where the lecturers on all four of the foundation disciplines were former primary or secondary teachers. The change moved the focus within the foundation disciplines to a more applied version of those disciplines, where lecturers used examples from practice to illustrate how theoretical constructs inform, illuminate and critique the day-to-day practices of schools and classrooms. Research conducted by Lyons et al (2003), drawing on Bourdieu's concept of cultural capital, was used to explore interactions between teachers and parents. Definitions of quality in education were examined in order to productively unsettle assumptions that link quality mainly to results in examinations. Engagement with theories of learning actively confronted assumptions that all pupils learn in the same way.

The changes to the HDE programme in the department that took place in the first decade of the $21^{\text {st }}$ century were incremental, occurring gradually during that period of time. Conversations with colleagues in the department, combined with reading literature about learning to teach and reflection on experiences as a student teacher, prompted us to think about how various aspects of the programme connected to each other in the minds and actions of student teachers. This correlated strongly with an orientation towards action research as part of professional practice: defining the issue, gathering and analysing data, using the literature and collegial conversations to bring different perspectives to guide the research, planning and implementing the plan, evaluating the results of the implementation, re-entering the cycle. There was also a strong engagement with reflective practice, inspired by the work of Brookfield in relation to critical reflection (Brookfield, 1995). Our autobiographies as teachers and learners, our students' eyes, the experiences of our colleagues and theoretical literature all played a role in informing the changes implemented year by year. The external examiner, who consults with both staff and students, noted that, since 2004, the programme as a whole became more integrated without sacrificing breadth, describing it as 'a copy-book example of imaginative, sustained and wise curriculum and assessment development'(External Examiner report, 2009-2010).

The changes are best understood thematically rather than chronologically and they are illustrated in the following four examples, namely: the integration of the foundation disciplines, Formative Assessment as a guiding principle, changes to placement practices, and pedagogical approaches.

\section{Integration of the Foundation Disciplines}

In the academic year 2007-2008, a new module entitled 'The Teacher as a Critically Reflective Practitioner' was introduced and taught in semester 1 of the programme. Developed through staff collaboration, this module drew three of the four foundation disciplines together in an integrated fashion in order to 
assist student teachers in the development of their practice and of integrated thinking about practices in teaching and learning. The assessment encouraged student teachers to draw on their practicum experiences to illustrate how particular theories informed or deepened their understanding of educational practices in the classroom and beyond. Each of these assessments was marked by at least two of the lecturers from the foundation disciplines, thus acting as a professional development opportunity for the academic staff teaching on the programme. This further developed the integration of theory and practice. In later years, student teachers from the Department's new undergraduate ITE programme also attended this lecture series. When the HDE (i.e. the postgraduate programme) later expanded to two years and the award became a Professional Master of Education (see article on 'The Professional Master of Education' in this volume) this interdisciplinary way of thinking provided a basis for the research work undertaken by the student teachers.

\section{Formative Assessment}

Developments in the HDE during the first decade of the $21^{\text {st }}$ century were also influenced by other work undertaken by the university's Education Department at that time. From 2002 to 2007, the department undertook a major research and development project, 'Teaching and Learning for the $21^{\text {st }}$ Century' (TL21), which involved working with experienced teachers on their continuing professional development. Staff in the department who were involved in the TL21 research also lectured and tutored on the HDE programme and ideas from this research naturally influenced the restructuring of the HDE. Formative assessment was one such idea. Prior to this, student teachers' placement had been assessed using a series of competency statements. A number of professional development seminars were run with the placement tutors resulting in the development of a rubric. This developed ownership of the grading mechanism and a common understanding among the team of tutors. The rubric was shared with the student teachers and they were invited to participate in a self-assessment exercise during the programme, thus raising their awareness of their own capabilities and of areas for development.

The Flanders Interaction Analysis Coding System assessment was replaced with a classroom-based action research project where student teachers choose a particular pedagogical area that they wish to understand in more depth and develop their capabilities within the classroom. Because the choice of topic was now within the students' control, it created an opportunity for them to critically engage with their own work. This also gave an impetus for engaging in professional conversations with their classmates and their tutors, not least in relation to issues of justice and inclusion.

Evidence gathered from our evaluation of the 2013 cohort of students revealed that the shift in thinking called for in taking an action research approach brought into the open some important conflicts, or contradictions, in assumptions. The following four were among the most frequently occurring examples:

- The contradiction between their experiences as pupils and their experiences as teachers: "I realised (slowly!) that I could not teach my students in the style that I was taught".

- The contradiction between a single way of learning and the multiplicity of ways of understanding the world: "I assumed everybody would be instantly be captivated by new pictures and new ideas brought to the classroom".

- The contradiction between teacher as subject expert with responsibility for transmission of that subject knowledge and the teacher as creator of environment of learning: "I was very textbook 
oriented which meant that I knew what I was teaching was correct but this fell short with my students. Some of my students found this information difficult to process while others found it easy to understand".

- The contradiction between their experience and the experiences of their pupils: "I assumed that reading newspapers would be a daily occurrence in the households of the pupils".

Technological developments in video recording also changed the video analysis system within the programme. Student teachers were now given responsibility to videotape themselves and engage in peer group analysis. This allowed them to video and view their own and others' classroom practices on at least two occasions during the year.

These initiatives encouraged student teachers to work in collaborative ways, confront conflicts in assumptions, to develop their professional capacities, and to strengthen their ethical agency. This involved the students not only in following a new approach to teacher education, but also in contributing to the development of the rationale for that approach.

\section{Placement Practices}

Corresponding changes were also made in placement practices. The placement tutors now gave a greater emphasis to utilising the student teachers' experiences within the classroom as prompts for discussion and reflection. Analysis of written post-supervision feedback to student teachers likewise placed a stronger focus to the following areas: preparation and planning, the student teachers' pedagogical actions during class and pupil involvement during the class. Our analysis of audio-recorded supervision conferences highlighted the following processes. Questions posed by placement tutors probed the pedagogical thinking of the student teachers so as to assist them in the articulation of their practices. Alternatives increasingly became co-constructed as the placement tutor brought his/her own authority of experience to the discussion; not as an authority of position but rather as a framework to guide the questions and the discussions. Within this kind of model, the tutor recognises that the student teacher has much to contribute to the process and that he/she may have a rationale for practice that is different but no less valid to that of the tutor.

\section{Pedagogical Approaches}

From what has been said in the above paragraphs it will already be clear that important changes were taking place in our pedagogical approaches in ITE. But the redesigned postgraduate programme still had to operate within certain timetabling and other constraints. Although the timetable remained structured in blocks of one-or two-hour lectures with a class size of 120 to 160 student teachers, lectures were rarely conducted in a traditional lecture format. The pedagogical approaches we developed at this time still remain definitive of our approach and they include the following. There is, to start with, the use of illustrated lectures, small group discussions, group work, showing video clips of teaching and inviting feedback from the student body. There is also an extensive use of digital resources to engage the student teachers during lectures. Student teachers are given time to engage in reflective journalling during the lectures as well as afterwards. Such approaches are congruent with Loughran and Russell's (1997) concept of modelling teaching for student teachers. Such approaches are less prone moreover to the ethical disablement that can develop among practitioners when 'theory' is placed in one compartment and 'practice' in another. Finally, such approaches emphasise how important it is to demonstrate through one's own practice as a teacher educator the ideals that underpin one's work. 
The productiveness of these integrated changes is evidenced in the comment by the external examiner (2009-2010) that "One sees and admires how 'theory' (not excluding the 'foundation disciplines' of philosophy, sociology, psychology and history of education) and practice resonate strongly in each other, mediated ... by classroom action research ... and a highly innovative module in Teacher as a Critically Reflective Practitioner...".

\section{Reviewing the Changes}

There is an acknowledgement in the account presented above that student teachers are adult learners, each with an experience of life that can be drawn upon. For instance, video recordings we have made of our own lectures regularly show the student teachers engaged in thinking about and commenting on their own experiences of teaching at certain points during the lecture. This strongly echoes the authority of experience described by Munby and Russell (1994): a form of knowledge-in-action (Schön, 1983) that can be drawn on and articulated by the student teacher as s/he learns to teach. This way of working uses the placement experiences of the student teachers as source material for reflection, not only during small group seminars, but also during lectures. The student teachers contribute their experiences as learners and as teachers to the lectures, resulting in a peer-learning model within which theoretical constructs are explored through reflection on practice.

As regards the lecturing staff, a 'meaningorientation' towards learning - i.e. an orientation towards improving performance through understanding the process of teaching and learning (Oosterheert et al., 2002) ${ }^{3}$, soon became evident. For instance in feedback interviews with a representative group of teacher educators on the programme, strong indications of such a meaning orientation emerged. This feedback revealed that when opportunities arose for these teacher educators to adopt an enquiry stance, they chose to do so. They engaged in conversations with others in an effort to understand the issue at hand, rather than merely looking for a way to solve the problem. They also demonstrated Schön's problem-setting approach to professional practice (Schön, 1983), as distinct from a problem-solving one. The meaning-orientation just mentioned was also observable in their practices as they taught the student teachers. Within this orientation, the teacher educators engage with the student teachers' experiences of teaching in ways that allow the student teachers to understand the 'why' as well as the 'what' of teaching. It is this orientation towards learning that acts as a prompt for the use of the 'authority of experience' (Munby \& Russell, 1994) as a teaching strategy. It is in this practice that the meaning-orientation of the teacher educators becomes visible.

Another key aspect to the development of the programme's ethical agency lay in the approach to the subject/pupil dichotomy. As distinct from merely working with competences, emphasis became placed more decisively on developing the student teacher's capability to teach his/her subject(s) with imagination and fluency through a series of subject-specific seminars; equally through a more generic series of seminars that emphasise key teaching and learning strategies. As mentioned earlier, student teachers have long been encouraged to view videotapes of their teaching in collaboration with others and to discuss their practices in relation to teaching and learning. The teachers, on this perspective, develop an ongoing and vibrant relationship with their teaching subjects; one that is a natural counterpart of their ongoing pedagogical relationship with their pupils.

The programme design was, and continues to be, informed by national and international research in the field; research that is congruent with the seven-point rationale mentioned earlier. Key perspectives from this research include the 
following: firstly, an in-depth understanding of the nature of quality in educational experience and of the criteria for analysing and evaluating it (Dewey,1938/1995); secondly, an understanding of the complex nature of a teacher's role, particularly dimensions such as: subject expert, skilled pedagogue, creator of positive learning environments, critically reflective practitioner and member of a professional community (Hoyle, 1974; Shulman, 2004; Teaching Council (2012); thirdly, the promotion of ways of thinking about the role of the teacher that recognise this complexity with its accompanying uncertainties and that offer frameworks for responding (Schön, 1984: Brookfield, 1995); fourthly, an appreciation of the importance of ITE as the first steps in the process of becoming a teacher and of the need to foster both a desire and a capability for continuing to learn and develop over the course of one's career; fifthly, the need to provide structured learning experiences in the university and in the school placements that allow the student teacher to engage with different ways of working with the diverse pupil population of the second level system (Feiman-Nemser, 2001: Darling-Hammond, 2006), requiring us to teach with the understanding of diversity as core to practice rather than as an optional add on; sixthly, an acknowledgement of the experiences of formal and informal education and of life that adult learners, including young adults, bring with them, requiring an awareness how adults learn (Knowles, 1984); and finally, a recognition of the socialisation impact of the 'apprenticeship of observation ${ }^{4}$ on student teachers' views of teaching (Lortie, 2002).

When Ireland's Teaching Council (2011) published Initial Teacher Education: Criteria and Guidelines for Programme Providers, this marked the first time in the history of the Irish State that the learning outcomes for graduates of ITE programmes were set out. Providers of ITE programmes were required to observe these criteria and guidelines in order to be accredited by the Teaching Council. The changes that had already been made to the HDE at the National University of Ireland Maynooth showed strong correlation with the Teaching Council's proposed national learning outcomes for ITE. Educating beginning teachers with the capacity to critically reflect on their practices, to change and renew such practices through both critical reflection and research, and to engage ethically with the myriad demands of educational practice, remain central goals for us. The article on the Professional Master of Education in this volume examines how these goals are taken up and embedded in a historic new professional qualification for Irish teachers.

\section{Notes}

${ }^{1}$ Two decades before independence James Joyce had scathingly remarked in his poem 'Gas from a Burner' (2012): 'Oh Ireland, my first and only love / Where Christ and Caesar are hand in glove'.

${ }^{2}$ Socrates doesn't put the matter as explicitly or as succinctly as this. It can be inferred however from the comments attributed to him by Plato in the 'Apology', but also from early Platonic dialogues like 'Euthyphro', 'Gorgias', 'Protagoras' and Bkl of 'Republic'.

${ }^{3}$ Oosterheert, Vermunt and Denessen (2002) define three orientations towards learning to teach: a meaning-oriented group, whose orientation towards improving performance was through understanding the process of teaching and learning; a reproduction-oriented group who improved performance by gathering cut and dried practical suggestions from those who were more experienced; and a survival-oriented group who had an undirected way of learning by making ad hoc adaptations to serious problems that emerged for them.

${ }^{4}$ Lortie (2002) uses the term 'apprenticeship of observation' to describe the process whereby primary and secondary students observe the actions of their teachers in classrooms, much like an audience viewing a play. This long period of 
observation of what teachers do in different classroom situations provides student teachers with default options that they can revert to in times of uncertainty. However these default options tend to be unexamined actions where the rationale behind the action is not understood, leading to an imitation of actions rather than an understanding of the pedagogical purposes behind such actions.

\section{References}

Aldridge, D. (2015). The Role of Higher Education in Teacher Education. In R. Heilbronn \& L. Foreman-Peck (eds.), Philosophical Perspectives on Teacher Education. Oxford: Wiley Blackwell.

Alexander, D., Chant, D. \& Cox, B. (1994). What Motivates People to Become Teachers, Australian Journal of Teacher Education, 19, 40-49.

Brookfield, S. D. (1995). Becoming a Critically Reflective Teacher. San Francisco: Jossey Bass.

Darling-Hammond, L. (2006). Constructing 21st-century teacher education, Journal of Teacher Education, 57, 300-314.

DENI (1998). The Northern Ireland Teacher Education Partnership Handbook. Bangor, NI: Department of Education, Northern Ireland.

Dewey, J. (1938/1995). Experience and Education. New York: Macmillan.

Dolan, R. \& Gleeson, J. (eds.) (2007). The Competences Approach to Teacher Professional Development: Current Practice and Future Prospects. Armagh: Standing Conference on Teacher Education North and South.

Drudy, S. \& Uí Chatháin, M. (2002). Gender effects in classroom interaction: Data collection, selfanalysis and reflection. Evaluation \& Research in Education, 16, 34-50.

Eide, E., Goldhaber, D. \& Brewer, D. (2004). The Teacher Labour Market and Teacher Quality. In Oxford Review of Economic Policy, 20, 230-244.

Elliott, J. (2012). Teaching controversial issues, the idea of teacher as researcher and contemporary significance for citizenship education. In J. Elliott. \& N. Norris, Curriculum, Pedagogy and Educational Research: The work of Lawrence Stenhouse (pp. 84-105). London and New York: Routledge.

Feiman-Nemser, S. (2001). From preparation to practice: Designing a continuum to strengthen and sustain teaching. Teachers College Record, 103, 1013-1055.

Flanders, N. A. (1970). Analyzing Teacher Behavior. Boston: Addison-Wesley Publishing Company.

Gilroy, P. (1998). New Labour and Teacher Education in England and Wales: The first 500 days, Journal of Education for Teaching, 24, 221-230.

Hillgate Group (1989). Learning to Teach. London: Claridge Press.

Hoyle, E. (1974). Professionality, Professionalism and Control in Teaching, London Educational Review, 3, 13-19.

Howson, J. (2012). The Future Teacher Workforce: Quality and Quantity. London: Pearson.

Johnson, S. M., Berg, J. H. \& Donaldson, M. L. (2005). Who stays in teaching and why: A review of the literature on teacher retention. Cambridge, MA: Project on the Next Generation of Teachers: Harvard Graduate School of Education.

Knowles, M. S. et al. (1984). Andragogy in Action: Applying modern principles of adult education. San Francisco: Jossey Bass.

Lawler, S. (1990). Teachers Mistaught: Training in Theories or Education in Subjects? London: Centre for Policy Studies.

Lawlor, Á. (2014). Transitions Toward Transformation: Exploring Continuing Professional Development for Teachers in Ireland. Unpublished PhD Thesis, Education Department, National University of Ireland Maynooth. 
Lortie, D. C. (2002). Schoolteacher: A Sociological Study, second edition. Chicago: University of Chicago Press.

Loughran, J. \& Russell, T. (1997). Teaching about teaching: Principles and practice. In Teaching about Teaching: Purpose, Passion and Pedagogy in Teacher Education, 57-69. Abingdon UK: RoutledgeFalmer.

Lyons, M., Lynch, K., Close, S., Sheerin, E. \& Boland, P. (2003). Inside Classrooms: The Teaching and Learning of Mathematics in Social Context. Dublin: Institute of Public Administration.

Maclure, S. (2008). Postscript: The spirit of the age, Oxford Review of Education, 34, 379-384.

Marshall, J. M. (2009). Describing the Elephant: Preservice Teachers Talk about Spiritual Reasons for Becoming a Teacher, Teacher Education Quarterly, 36, 25-44.

Munby, H. \& Russell, T. (1994). The Authority of Experience in Learning to Teach: Messages from a Physics Methods Class, Journal of Teacher Education, 4, 86-95.

OECD (2005). Teachers Matter: Attracting, Developing and Retaining Effective Teachers. Paris: Organisation for Economic Cooperation and Development.

Oosterheert, I. E., Vermunt, J. D. \& Denessen, E. (2002). Assessing orientations to learning to teach, British Journal of Educational Psychology, 72, 41-64.

Plato (1999). Euthyphro. Apology. Crito. Phaedo. Phaedrus. Translated by J. N. Fowler. Cambridge MA: Harvard University Press - Loeb Classical Library.

Sahlberg, P. (2011). Finnish Lessons: What can the world learn from educational change in Finland? New York: Teachers College Press.

Schön, D. (1983). The Reflective Practitioner. London: Temple Smith.

Shulman, L. S. (2004). The Wisdom of Practice: Essays on Teaching, Learning, and Learning to Teach. San Francisco: Jossey Bass.

Stenhouse, L. (1979/2012). Research as a basis for teaching, Inaugural Lecture of 1979 at the University of East Anglia, reprinted in 2012. In J. Elliott \& N. Norris, Curriculum, Pedagogy and Educational Research: The work of Lawrence Stenhouse (pp. 122-136). London and New York: Routledge.

Teaching Council (2011). Initial Teacher Education: Criteria and Guidelines for Programme Providers. Maynooth: The Teaching Council.

Teaching Council (2012). Code of Professional Conduct for Teachers, Second Edition. Maynooth: The Teaching Counci.

\section{Resumen}

Dando forma a un nuevo paisaje ético en la formación de maestros: una experiencia irlandesa en un contexto internacional

INTRODUCCIÓN. Se revisa la transformación gradual y decisiva en la formación de maestros en Irlanda. Se empieza esbozando los modelos tradicionales de formación de maestros, que imitaban a los del Reino Unido. Estos modelos rara vez abordaban las dimensiones éticas del aprendizaje del profesional; consistían, por un lado, en el conocimiento teórico, y, por otro, en la iniciación en actitudes y habilidades para sobrevivir en el lugar de trabajo. El presente artículo examina los esfuerzos sucesivos para cambiar estos modelos. MÉTODO. Se toma un estudio que ilustra los esfuerzos de una universidad para transformar este patrón conformista. El artículo explora cómo una nueva lógica surgió durante la década de los 80 y triunfó en las décadas siguientes. Se presta atención a preocupaciones como la cuestión ética del maestro, 
la capacidad de reflexión y el liderazgo pedagógico. La estructura de investigación tiene cinco partes. La primera esboza el contexto histórico, revelando cómo las dimensiones éticas de la enseñanza a menudo permanecieron aisladas de la formación de maestros. La segunda explora las diferentes trayectorias de la formación de maestros en el UK e Irlanda en los 80 y hace un resumen de la nueva lógica desarrollada en Maynooth. La tercera revisa la noción de agencia ética y su importancia para tal lógica. La cuarta ilustra cómo la nueva lógica produjo cambios en las experiencias prácticas de la formación de maestros, especialmente a través del diploma superior en Educación. La sección final revisa las consecuencias del nuevo enfoque y su importancia para la política nacional en un momento en que un nuevo órgano nacional (el Consejo Docente) adoptó un enfoque crítico reflexivo de la formación de maestros. RESULTADOS. Los resultados se analizan gradualmente a lo largo del documento para mostrar cómo las dimensiones éticas del aprendizaje profesional se volvieron más centrales y más fructíferas. DISCUSIÓN. Se centra en las acciones necesarias para hacer más relevantes y significativas las dimensiones éticas del aprendizaje profesional.

Palabras clave: Cuestión ética, Capacidad reflexiva, Investigación informada por la práctica.

Résumé

Formuler une nouvelle Ethique dans la formation des enseignants: Un exemple irlandais dans un contexte international

INTRODUCTION. Cet article fait le bilan d'un changement progressif mais définitif dans le programme de formation des enseignants en Irlande. Dans un premier moment il retrace les grandes lignes du modèle traditionnel de la formation des enseignants, historiquement basé sur le système de formation anglais. Celles-ci ne traitent que rarement et pas directement la dimension éthique de l'apprentissage professionnel. Un tel apprentissage consistait principalement, d'une partie de la théorie, et d'une autre partie de la pratique des attitudes héritées ou bien des méthodes pour survivre dans les établissements scolaires. Cet article étudie les efforts successifs mis en place pour changer ces modèles. MÉTHODE. Cette étude, prend pour exemple les efforts mis en place par une université pour transformer ce modèle. Nous explorons comment une nouvelle logique a vu le jour dans les années 80 et a été progressivement mise en place. Une attention toute particulière est portée sur l'importance de l'éthique des enseignants en tant qu'agence et leur capacité réflexive. Cette recherche est structurée en cinq parties. La première fait le schéma du contexte historique, mettant en valeur comment les questions primordiales sur l'éthique restent souvent en arrière plan dans la formation des enseignants. La deuxième retrace les différentes directions prises par la formation au Royaume-Uni et en Irlande dans les années 80 et résume la nouvelle logique développée à Maynooth. La troisième examine la notion de 'agence éthique', et de son importance pour la logique mentionnée. La quatrième illustre comment cette nouvelle logique a changé l'expérience des futurs enseignants, spécialement à travers du diplôme d'études supérieures spécialisées en Éducation ; ('HDIP'). La dernière partie fait la révision des conséquences de cette nouvelle approche et ses implications au niveau des réformes nationales, à un moment où, en Irlande, le Teaching Council (Conseil national des enseignants) adopte pour vision d'ensemble une approche critique et réflexive de la formation pédagogique. RÉSULTATS. Les résultats de cette nouvelle approche sont revus de manière progressive et systématique tout au long de cet article, pour révéler comment les dimensions éthiques de l'apprentissage 
professionnel, devenues importantes, connaissent un tel succès. DISCUSSION. le débat, tout au long de cet article, repose sur l'élaboration des actions nécessaires, pour que la dimension éthique de l'apprentissage soit à la fois pertinente et significatif.

Mots-clés: Agence Ethique, Capacité de réflexion, Méthode informée par la recherche.

\section{Author Profile}

\section{Rose Dolan (Corresponding Author)}

Dr Rose Dolan is a Lecturer in Education at the National University of Ireland Maynooth. Her research interests focus in particular on teacher education and educational leadership. She is coauthor (with Brendan Walsh) of A Guide to Teaching Practice in Ireland (2009), which is extensively used in teacher education programmes. She has published widely in a range of formats, her most recent paper being 'Competencies in Teaching, Learning and Educational Leadership in a Digital Age' (2016).

E-mail: rose.dolan@nuim.ie

Correspondence Address: Dr Rose Dolan, School of Education, National University of Ireland Maynooth, Maynooth, Co. Kildare, Ireland.

\section{Pádraig Hogan}

Dr Pádraig Hogan is a Senior Lecture in Education at the National University of Ireland Maynooth. His research interests include: educational experience and educational environments; justice and equality in educational practice; international developments in educational policy research. His publications number over 100 items, including articles, chapters and books. His most recent book is The New Significance of Learning: Imagination's Heartwork (2010).

E-mail: padraig.hogan@nuim.ie 